\title{
北海道における人工内耳装用児の就学と 教育機関との連携に関する害態調査
}

\author{
鈴木美華，柏村正明，武市紀人，小原修幸，福田 諭 \\ 北海道大学大学院医学研究科耳鼻咽喉科・頭頸部外科
}

\begin{abstract}
要旨: 北海道内の人工内耳装用児を取り巻く教育環境の実態を把握し, 今後の課題につい て検討する目的で, 襲学校・難聴学級・難聴通級指導教室学級担任の質問紙調查を実施し た。調查の結果から, 人工内耳装用児が在籍する聾学校と医療機関との連携については, 術前からの定期的なカンファレンスの実施が機能していると考えられた。一方で, 難聴学 級・難聴通級指導教室と医療機関との連携は不十分であることが明らかになった。また, 装用児の就学に関して, 聾学校学級担任・難聴学級・難聴通級指導教室担当教員と医療機 関の連携が必須であり, 就学先の環境整備が人工内耳装用児の通常学級就学の重要な要件 であると考えられた。今後, 聾学校との連携を継続するとともに, 難聴学級・難聴通級指 導教室を対象に連携を拡大し, 環境整備を含めた装用児の支援体制の確立に取り組む必要 があると考えられた。
\end{abstract}

$$
\text { ーキーワードー }
$$

人工内耳, 装用児, 聾学校, 難聴学級, 就学

\section{はじめに}

本邦では1991年より小児に対する人工内耳埋め込 み手術が始まり高度難聴幼児の聴覚・音声言語獲得 に大きな進歩をもたらしだ。特に音声言語獲得の ためには，手術のみならず術前術後の療育が重要な 役割を果たしている。当科では, 小児人工内耳埋め 込み手術を開始した2000年からは，医師と言語聴覚 士, 襲学校教員による定期的なカンファレンスや勉 強会を実施し, 相互の連携に基づいて術前からの聴 覚学習・言語指導を行っている。当科と稩学校の人 工内耳埋め込み手術における連携の背景には, 章学 校が北海道の聴覚障害児の教育を担う唯一の施設で あること, 当科が1980年から北海道札幌壟学校へ学 校医を派遣し，1996年からは毎月の定期健診と耳鼻 科相談業務を行うなどの歴年の協力関係が存在す る。人工内耳装用児に対する聴覚学習・言語指導を 含む支援に関しては，地域や施設ごとに必ずしも一
様ではないと考えられるが, 近年, 全国的に通常学 級へ就学する装用児は増加傾向にあると考えられて いる ${ }^{2)}$ 。同様に，当科においても多くの装用児とそ の家族が通常学級への就学を希望している。しかし ながら, 就学後も当科において個別指導や経過観察 を継続している児童が多数存在するのが現状であ る。そこで, 本報告では, 北海道内の聾学校・難聴 学級・難聴通級指導教室学級担任を対象に質問紙調 查を実施し，人工内耳装用児を取り巻く教育機関の 現状把握とともに就学に関する課題について検討を 行った。

\section{対象・方法}

2006年 5 月に北海道内の壟学校 8 校の乳幼児相談 室・幼稚部 - 小学部 · 中学部 ·高等部 80 学級, 小中 学校難聴学級 20 校 20 学級, 小中学校難聴通級指導教 室 5 校 5 学級, 計 33 校 105 学級の担当教員を対象 に，郵送による質問紙調査を実施した。質問紙調査 
表 1 アンケート内容

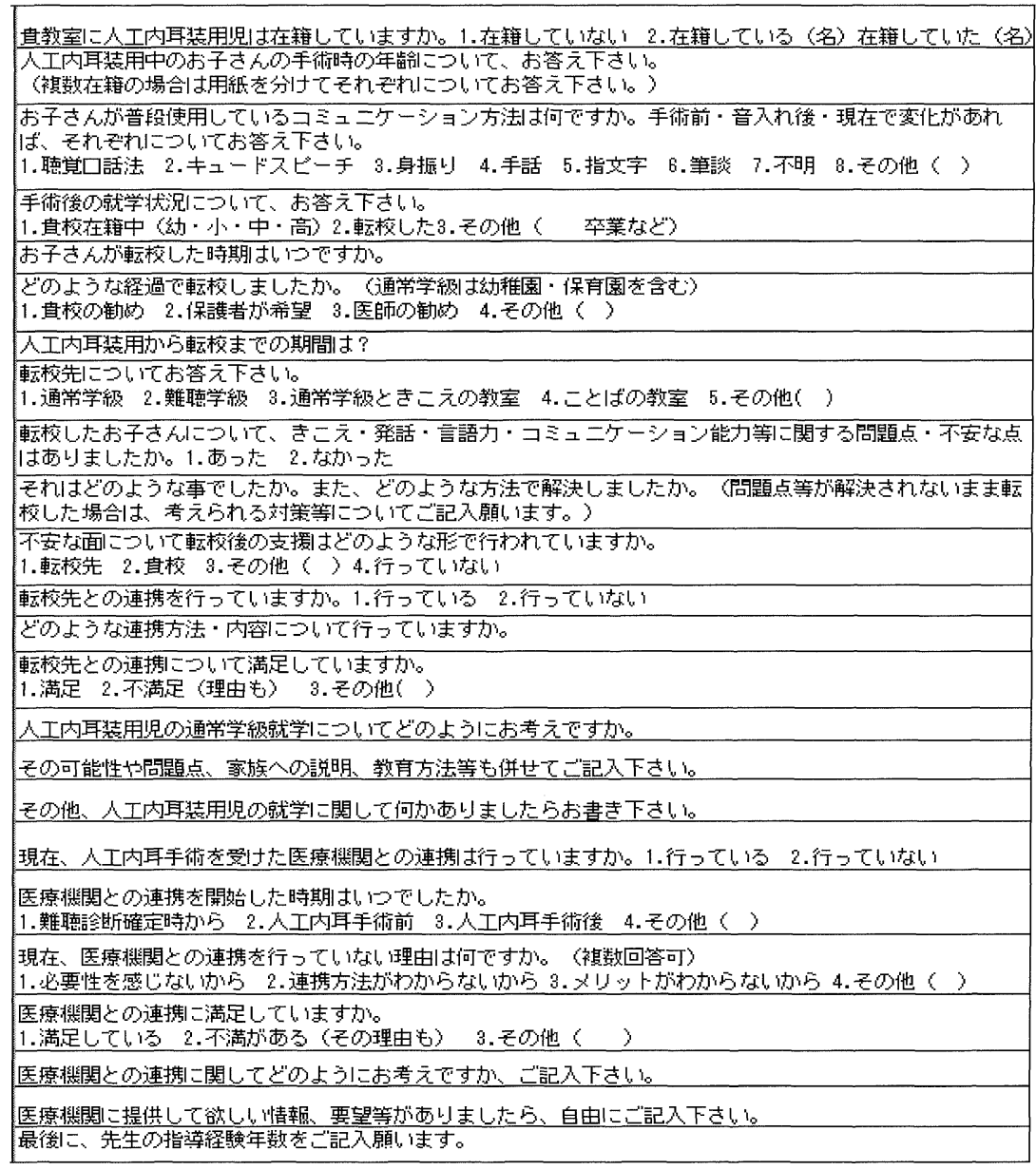

は, 各学校の学級担当教員に依頼し， 1 学級に複数 の担当教員がいる場合はそれぞれの教員に個別に回 答を求めた。内容は，主に「人工内耳装用児の在籍 数」「医療機関との連携状況」「人工内耳装用児の通 常学級就学状況と課題」に関するもので，無記名及 び個人情報保護の観点より，個人を特定する情報が 含まれない形式で調査を進めた（表 1 ）。回答は項 目別に用意し， 1 学級に複数の担任がいる場合や過 去に装用児が在籍していた場合に装用児が重複しな いよう配慮した。「医療機関との連携状況」につい ては，担任の変更や手術により将来的に装用児を担 当する可能性が全教員にあることを踏まえ，装用児 在籍の有無に関わらず，現時点での人工内耳におけ る医療機関と教育機関の連携状況や考えについて回 答を求めた。回収された内容に基づき, 現状と課題 について検討を行った。

\section{結果}

道内聾学校 8 校中 8 校, 80 学級中 56 学級 $(70 \%)$ 59 名, 道内難聴学級 20 学級中 6 学級 $(30 \%) 6$ 名, 難聴通級指導教室 5 学級中 2 学級 $(40 \%) 2$ 名, 計 16 校64学級67名の回答が得られた。回答した襲学校 教員の指導経験年数は，平均約14年（2 年一 50 年） であった。難聴学級・難聴通級指導教室教員の指導 経験年数は, 1 年一 7 年が 5 名, 20 年以上が 3 名で あった。

1）人工内耳装用児の在籍数

北海道内の人工内耳手術実施施設と本調查で把握 できた壟学校に在籍する人工内耳装用児の分布を地 図に示す（図 1 )。装用児は 5 校 24 学級に 34 名であ り, 内訳は, 乳幼児相談室 4 名, 幼稚部15名, 小学 部12名, 中学部 0 名, 高等部 3 名であった。各聾学 校の生徒数に対する装用児の割合は，北海道立札幌 


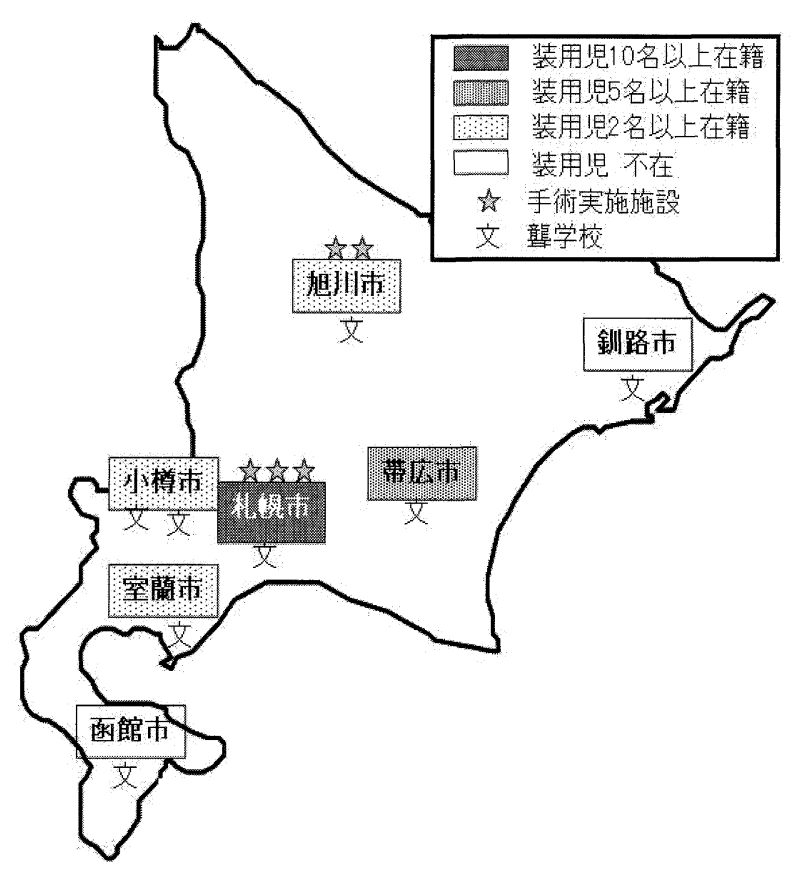

図 1 道内の人工内耳実施施設と聾学校における 装用児在籍数

龍学校が全生徒数の約14\%（142名中20名）, 北海道 立帯広龍学校約 $26 \%$ (27名中 7 名), 北海道立小樽 高等聾学校約 $3 \%$ (96名中 3 名), 北海道立旭川韵 学校約 $3 \%$ (57名中 2 名), 北海道立室蘭聾学校約 $33 \%$ （6 名中 2 名）であった。装用児不在の聾学校 については，北海道立小樽聾学校 0\%（12名中 0 名), 北海道立函館襲学校 0\% (15名中 0 名), 北海 道立釧路聾学校 $0 \%(9$ 名中 0 名）であった。ま た，当科で手術した装用児の内訳は札幌聾学校 14 名, 帯広龍学校 2 名, 旭川聾学校 1 名, 室蘭聾学校 1 名であった。人工内耳実施施設は札幌市と旭川市 に集中しており，施設から距離が離れるに従い装用 児在籍数が減少する傾向にあった（図 1)。

また, 回答の得られた難聴学級に在籍する装用児 は 0 名, 難聴通級指導教室に通級する装用児は 2 教 室 4 名（1教室各 2 名）であり，4名とも通常学級 に在籍していた。聾学校教員が把握している難聴学 級に転校した装用児は 1 名, 通常学級へ転校した装 用児は 1 名であった。装用児の手術時の年齢, 転校 時期などの調査結果から難聴通級指導教室で把握す る 4 名と聾学校教員が把握する 2 名の重複はなく, 本調査で把握できた難聴学級及び通常学級に在籍す る装用児は 6 名であった。

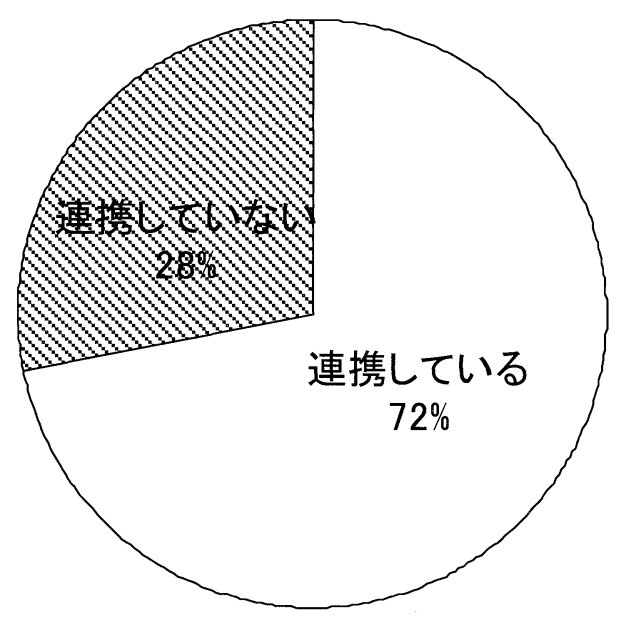

図 2 聾学校教員 29 名と医療機関の連携

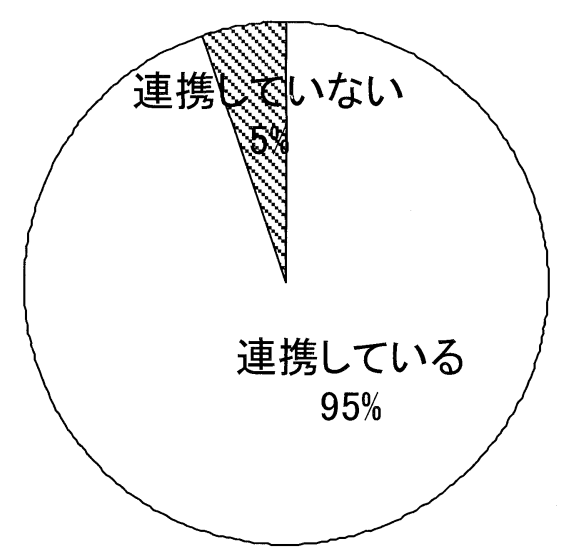

图 3 装用览を担当している聾学校教員 19 名と 医療機関との連携

2) 医療機関との連携

<聾学校と医療機関との連携 $>$

壟学校29名の教員から回答が得られ，そのうち21 名 $(72 \%)$ が医療機関との連携があり，8名 $(28 \%)$ は連携がなかった（図 2 )。回答が得られた 29 名の 教員のうち, 人工内耳装用児が在籍している学級の 担当者は19名, 残り 10 名は装用児が在籍していない 学級の担当者であった。装用児を担当している学級 の教員19名のうち18名 $(95 \%)$ の教員が医療機関と 連携があり，残り 1 名 $(5 \%)$ は「担任が変更して 間もない」と言う理由から連携がなかった（図 3 )。 装用览を担当し医療機関と連携がある18名の教員の 連携開始時期は, 難聴診断確定時 6 名, 術前 9 名, 術後 3 名であった。連携方法については，「定期的 なカンファレンスの実施」が10名 $(56 \%)$,「随時, 


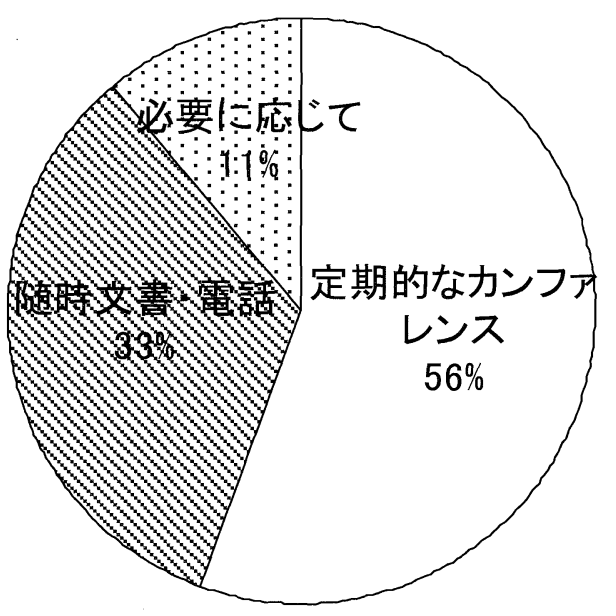

図 4 装用児を担当し連携のある襲学校教員18名の連携方法

文書・電話を用いて害施」が 6 名 $(33 \%)$,「必要に 応じて実施」が2名（11\%）であった（図 4$) 。$ 連 携の内容については, 装用児に関する情報交換が行 われており，教育機関から医療機関へは言語指導の 内容や聴覚活用・言語発達の状況, コミュニケーシ ヨンの様子について, 医療機関側から教育機関へ は, マッピングの様子や聴覚活用の様子, 言語指導 の内容についてそれぞれ情報提供が行われていた。 一方，装用児が在籍していない学級の教員 10 名のう ち，3名 $(30 \%)$ が医療機関と連携があり，7名 （70\%）は連携がなかった。装用児不在で医療機関 と連携がある学級の教員 3 名中 2 名は, 定期的なカ ンファレンスを利用し, 人工内耳に関する最新の機 器の情報などを得ており, 他 1 名は学校の教育相談 担当者が悹口となり, 医療機関との情報交換を行な っていた。連携を行なっていない 7 名の理由につい ては，「装用児や治療が必要な生徒がいない」6 名，「連携方法がわからない」1名であった。

「医療機関との連携に満足しているか」という設 問には，8名の教員が回答し，8名中 7 名が満足し ていると答え, 残り 1 名は「担任が変更したばかり でまだわからない」と答えた。また，連携に関する 考えを自由記述としたところ，19名の襲学校教員か ら回答が得られた。回答の内容は，「連携は重要で ある」とする意見16名,「現在の定期的な連携に満 足している」という意見 6 名，「連携に関する要望」 2 名であった。「連携は重要である」と回答した 16 名中 7 名は「定期的な協議の場が必要」と指摘した。

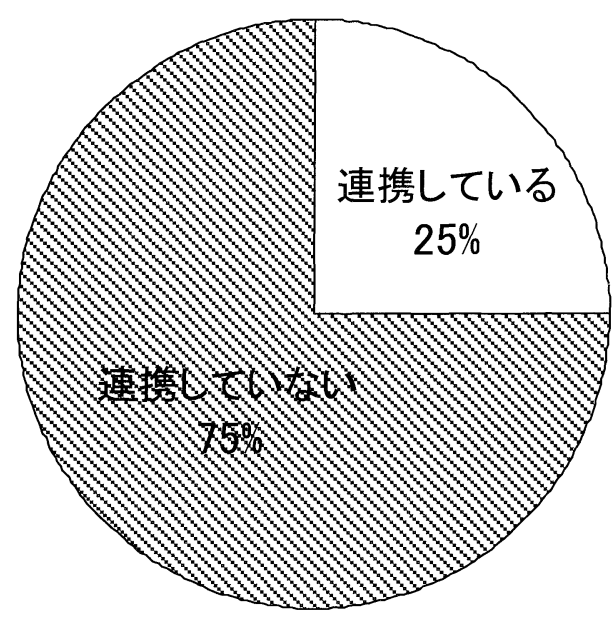

図 5 難聴学級・通級指導教室教員 8 名と医療機関の連携

「連携に関する要望」としては，「医療機関から教育 機関へ電話をする場合の時間带について配慮して欲 しい」と，「人工内耳の日常の注意する点について 教えて欲しいと」する意見が認められた。連携に当 たり医療機関から提供して欲しい情報としてあげた のは, 人工内耳の基礎的な情報 (手術, 機器の取り 扱い，日常の配慮など） 5 名，マッピングのデー夕 4 名, 最新の機器や技術に関する情報 3 名, 装用児 が高校・大学へ進学した事例に関する情報や術時年 齢と言語発達の経過を比較できる事例に関する情報 2 名であった。

<難聴学級・通級教室と医療機関との連携 $>$

回答が得られた難聴学級・難聴通級指導教室 8 校 8 名のうち，連携ありが 2 名 $(25 \%)$ であり，残り 6 名 $(75 \%)$ は連携がなかった（図 5$)$ 。人工内耳 装用児が在籍している 2 学級 2 名の教員において は，連携を行っていなかった。連携を行っている 2 名の連携方法については,「定期的な診察を実施し ている」が1名,「必要に応じて連携している」が 1名であった。連携を行っていない理由について は,「装用児や治療が必要な生徒がいない」3名,「意 欲はあるが連携方法がわからない」が 3 名, 装用児 不在と連携方法が不明の両方を選択したものが 1 名 であった。また，医療期間との連携に関する自由回 答として「連携意欲はあるが方法がわからない, 打 ち合わせの時間がお互いに取れるのかなど全くわか らず，なかなか取り組めずにいる」との記述が含ま 
れていた。難聴学級・通級教室教員が医療機関から 提供して欲しい情報としてあげたのは，人工内耳の 基礎的な情報 4 名, 機器の最新情報 1 名であり，そ の他「わからない事が多いので，たくさんの情報が 欲しい」，「経験年数はあっても専門の知識，技能を もっていないので，手探り状態」といった回答も認 められた。

3 ）人工内耳装用後の通常学級就学状況と課題

本調查で把握できた難聴学級及び通常学級に在籍 する装用児 6 名の就学後の状況として， 6 名中 2 名 は周囲とのコミュニケーションが良好で特別な指導 を必要としない経過観察のみが行われていた。他 4 名は，発音の問題や言語力・集団でのコミュニケー ション能力不足を指摘され，個別指導を必要として いた。個別指導を受けている 4 名中 3 名は, 難聴通 級指導教室や医療機関で語彙力や読解力・コミュニ ケーションに関する指導が行われ，他 1 名は聾学校 が発音指導を行っていた。壟学校における発音指導 に関しては，「月 1 度の指導には困難がある」との 意見が添えられていた。

装用児の通常学級就学に関する課題について自由 記述としたところ，46名の聾学校教員から回答が得 られた。回答の内容を大別すると，「就学先の担任 の知識や配慮不足」，「周囲への啓蒙不足」などの環 境面の指摘が11名，聾学校と通常学級，教育機関と 医療機関の連携の必要性を指摘する意見 8 名であっ た。また，装用児側の条件として，聴取能や発音面 よりも言語力や思考力, 社会性, コミュニケーショ ン能力等が重要とする意見が 8 名認められた。難聴 学級・難聴通級指導教室担当教員からは，5名の回 答が得られ，環境面の指摘が 2 名，「人工内耳に対 する教員の知識不足」「医療機関との距離的問題か らその後のフォローに不安がある」という意見が 2 名, 装用児側の条件として, 聴取能よりもコミュニ ケーション能力が必要とする意見が 1 名認められ た。

\section{考察}

<人工内耳装用児を取り巻く教育機関の現状 $>$ 「人工内耳装用児の在籍数」

本調査により，道内の装用児数は，聾学校ごとに 偏りが認められた。竟学校の生徒数と装用児数に相
関は認められないことから, 聾学校の生徒数の差が 全ての要因とは断定できず，背景として，北海道の 特殊な地域性及び道内の人工内耳実施施設が道央圈 と呼ばれる都心部へ集中し，その広域性に比し少な いことが考えられる（図 1)。実際に，装用児が不 在であった函館市や釧路市は実施施設への通院に電 車で片道 4 時間以上要するため, 現実には通院や緊 急時の対応，施設間の連携が困難であると考えられ る。本調査においては，距離的問題を理由に手術を 見合わせた適応児の有無については把握できなかっ たものの，今後，実施施設との距離的問題が及ぼす 影響等について更なるを検討を要すると考える。ま た，医療資源のそしい地域における聴覚障害児とそ の家族に効果的かつ効率的な支援を提供するために は，当科を含めた実施施設と遠隔地域施設との連携 が必要と考える。一つの方策として，電子メールや ホームページなどの媒体を利用する方法などが考え られるが，個人情報保護の問題や地域主幹施設の確 保に加え, 道内 5 施設の人工内耳実施施設間の連携 をどのように行うのかといった課題も多い。今後, 北海道の地域性を踏まえ, 専門性を持つ医師の定期 的な派遣や地域病院と人工内耳実施施設との密接な 連携といった総合的かつ組織的な地域医療支援体制 の検討が望まれる。

\section{「医療機関との連携」}

小児人工内耳に扔ける医療機関と教育機関との連 携に関しては，日本耳鼻咽喉科学会の小児人工内耳 適応基準において「手術前から術後の療育に至るま で，専門職種との一貫した協力体制がとれているこ と」が前提条件として明記されている。高橋らは, 人工内耳装用児と教育機関における全国的な実態調 査の中で，教育・療育機関と医療機関の連携は多く の施設間で行われているものの，術前から定期的な 連携指導がなされていない実情を明らかにし，関係 諸機関が人工内耳の適応から話し合うことが望まし いと指摘している ${ }^{3 / 4)}$ 。本調査結果においても, 聾学 校においては人工内耳装用児が在籍する学級の教員 19名のうち，18名（95\%）においては，医療機関と の連携が行われており，連携を行っている半数の壟 学校教員が医療機関との難聴診断確定時及び術前か らの定期的なカンファレンスを実施していた。一方 
で, 難聴学級・難聴通級指導教室と医療機関との連 携については，8名中 2 名 $(25 \%)$ のみが連携を行 っており，人工内耳装用児が在籍する学級の教員 2 名については, 連携を行っていないことから, 連携 が不十分であると考えられた。難聴学級・難聴通級 指導教室については, 装用児の術前から医療機関と 協力体制をとることは難しく，その後の連携が進ま ないといった現状も考えられることから, 人工内耳 実施施設である医療機関側からのより積極的な働き かけが必要であると考えられた。

また，連携に関する襲学校・難聴学級・難聴通級 指導教室教員の共通の要望は, 人工内耳の基礎的な 情報（手術や機器の取り扱い, 日常の配慮など）や 最新情報の提供であったが, 難聴学級・難聴通級指 導教室教員は人工内耳のみならず聴覚全般に関する 情報が不足し, 指導に困難を感じている現状が示唆 された。今後の課題として, 各施設との直接的な話 し合いの場を設け, 人工内耳を含めた聴覚障害全般 に対する知識の普及・啓蒙を目的とした多くの関係 者が参加可能な勉強会に類する会合の開催などを模 索することが望ましいと考えられた。

また，本調查において回答が得られた壟学校学級 担当教員 59 名のうち医療機関との連携に回答を寄せ たのは29名（装用児在籍19名, 不在10名）であり, 医療機関との連携に関する項目のみの回収率は, 装 用児が在籍する学級担当教員 27 名中 19 名 $(70 \%)$, 装用児不在の学級担当教員は32名中10名 $(30 \%)$ で あった。本調査においては，担任の変更や手術によ り将来的に装用児を担当する可能性があることを踏 まえ, 装用児在籍の有無に関わらず, 現時点での医 療機関との連携状況について回答を求めたが, 結果 的に装用児不在の学級担当教員からの「医療機関と の連携」に関する項目の回収率は低かった。本調査 の結果が全ての装用児及び教育機関の実状を反映し ていない可能性も考えられることから，今後更なる 検討を要すると考える。

\section{$<$ 人工内耳装用後の通常学級就学状況々課題 $>$}

本研究の結果からは, 龍学校学級担任・難聴学 級・難聴通級指導教室担当教員は, 就学先の環境整 備が人工内耳装用児の通常学級就学の重要な要件で あると考えていることがわかった。また，本調査で
把握できた通常学級へ就学した装用児の多くが, 発 音の問題や言語力に加えて集団でのコミュニケーシ ヨン能力に関する問題を抱え, 就学後も個別指導を 必要としていた。小児人工内耳における通常学級就 学に関しては, 同様に様々な問題が報告されてお $\eta^{5) 6}$ ，川野らは，通常学級就学後に人工内耳装用児 が，対人関係や集団生活のルールなど社会性の問題 や聴覚障害の受容などの心理的な問題に直面した事 例をあげ，多領域の専門家による支援の必要性を指 摘している ${ }^{6) 7}$ 。装用児が通常学級へ就学する場合 は, 就学前に人工内耳の啓蒙や環境調整を行うこと はもちろん, 就学後に生じてくる問題に対する支援 や連携方法, 個別指導が必要な場合はどの機関がど のような方法で行うのかといった事項に関して，具 体的に決定しておくことが重要であると考える。当 科では，これまで装用児が通常学級就学を希望する 場合, 聾学校学級担任・難聴通級指導教室・難聴学 級教員と連携し, 人工内耳の㤵蒙や環境調整を含む 就学前支援を個別に行っている。就学後は, 定期的 な経過観察を継続し，装用児が通う通級教室との情 報交換を行い，要望に応じて個別指導を行うなどし ている。これらの活動は, 今後も継続していくこと が望ましいと考える。しかしながら，通常学級へ就 学する装用児増加に伴う我々医療機関側の活動に費 やす時間及び人的資源の確保など課題も残る。本調 查で把握した北海道内の装用览の多くは, 現在, 幼 稚部から小学部に在籍している。今後, 教育機関 • 医療機関合同の就学検討会や就学後の定期的なカン ファレンスの実施を行うなど，早急な支援体制の確 立に取り組む必要があると考えられる。

\section{まと め}

道内の人工内耳装用児を取り巻く教育環境の実態 を把握する目的で, 襲学校・難聴学級・難聴通級指 導教室学級担任の質問紙調查を実施した。実態調查 の結果から, 人工内耳装用児が在籍する壟学校と医 療機関との連携については, 定期的なカンファレン スを始めとする活動の有効性が示唆された。一方 で, 難聴学級・難聴通級指導教室と医療機関との連 携は不十分であることがわかった。また，装用児の 就学に関しては, 聾学校学級担任・難聴学級・難聴 通級指導教室担当教員と医療機関を含めた総合的な 
支援が必要であり, なおかつ, 就学先の環境整備が 人工内耳装用児の通常学級就学の重要な要件である ことが明らかとなった。今後の課題として, 聾学校 との連携を継続するとともに, 難聴学級・難聴通級 指導教室との連携を拡大し, 勉強会や情報交換会を 開催するなど，人工内耳についての啓蒙や環境整備 を含めた装用児の支援体制の確立に取り組む必要が あると考えられた。また，北海道においては，特殊 な地域性を踏まえた地域医療支援体制の検討が望ま れると考えられた。

The study of the cooperation between schools for hearing-impaired students and medical institutions in Hokkaido

Mika Suzuki, Masaaki Kashiwamura, Norihito

Takeichi, Nobuyuki Obara, Satoshi Fukuda

Department of Otolaryngology, Hokkaido University School of Medicine

An opinion poll was conducted among the teachers of schools for the hearing-impaired or deaf students in Hokkaido, with the purpose of clarifying the present state of the educational environment of children with cochlear implants and to identify any problems that they might have. The results suggested the existence of adequate cooperation between the schools for deaf students, including students with cochlear implants, and medical institutions. The periodic meetings, which were started pre-surgically, were thought to be particularly effective. On the other hand, poor cooperation existed between the schools for hearing-impaired students who were not deaf, and medical institutions. When children with cochlear implants try to enter regular schools, special support from those schools and institutions is necessary and classes need to be prepared to accept children with cochlear implants. It is important not only to continue the cooperation with schools for deaf students, but also to create better cooperation with the schools for hearing-impaired students. In addition, we need to establish a system for supporting those children with cochlear implants who wish to enter ordinary schools.

\section{参考文献}

1 ) 中島八十一, 森浩一, 柴田貞雄: 人工内耳装用 児等の言語習得訓練状況についての全国調査の結 果。Audiology Japan 46: 411-412, 2003

2 ）柳原尚明, 阿部厚仁, 井上靖二, 他: 難聴児童 生徒へのきこえの支援。聴力調整指導小委員会作 成, 日本学校保健会発行, 2004

3 ) 高橋信雄, 立入哉: 壟学校における人工内耳一 の対応の実情。Audiology Japan 40:559-560, 1997

4 ）高橋信雄, 立入哉: 通常学級に在籍する人工内 耳装用児の実態。Audiology Japan 41：425-426, 1998

5 ) 田中美郷, 芦野聡子, 小山由美, 他: 通常学級 に入学した人工内耳装着児のかかえる教育上の問 題。Audiology Japan 47 : 525-526, 2004

6 ）川野通夫, 本庄嚴, 内藤泰, 他: 人工内耳装着 学童への援助。音声言語医学 $37: 378-382,1996$ 7 ）川野通夫：〔11〕小・中学校との連携。本庄嚴 編, 小児人工内耳 川井弘光, 川原出版, 東 京, 2002，117-128

（原稿受付 平成19.3.31）

別冊請求先： $\bar{\top} 060-8638$ 北海道札幌市北区北15条 西 7 丁目北海道大学大学院医学研究科 耳鼻咽喉科・頭頸部外科分野 鈴木美華

\section{Reprint request :}

Mika Suzuki

Department of Otolaryngology, Hokkaido University School of Medicine, N15W7, Kita-Ku, Sapporo, Hokkaido, 0608638, Japan 